\title{
Markets, regulation and drug law reform: Towards a constitutive approach
}

DOI:

$10.1177 / 0964663919868756$

\section{Document Version}

Accepted author manuscript

Link to publication record in Manchester Research Explorer

\section{Citation for published version (APA):}

Seddon, T. (2019). Markets, regulation and drug law reform: Towards a constitutive approach. Social \& Legal Studies, 29(3), 313-333. https://doi.org/10.1177/0964663919868756

\section{Published in:}

Social \& Legal Studies

\section{Citing this paper}

Please note that where the full-text provided on Manchester Research Explorer is the Author Accepted Manuscript or Proof version this may differ from the final Published version. If citing, it is advised that you check and use the publisher's definitive version.

\section{General rights}

Copyright and moral rights for the publications made accessible in the Research Explorer are retained by the authors and/or other copyright owners and it is a condition of accessing publications that users recognise and abide by the legal requirements associated with these rights.

\section{Takedown policy}

If you believe that this document breaches copyright please refer to the University of Manchester's Takedown Procedures [http://man.ac.uk/04Y6Bo] or contact uml.scholarlycommunications@manchester.ac.uk providing relevant details, so we can investigate your claim.

\section{OPEN ACCESS}




\title{
Markets, regulation and drug law reform: Towards a constitutive approach
}

\author{
Toby Seddon \\ School of Law \\ University of Manchester \\ UK \\ toby.seddon@manchester.ac.uk
}

\author{
[Accepted for publication in Social \& Legal Studies]
}

\begin{abstract}
After a century of international drug prohibition, and amidst growing consensus that it has been a costly policy failure, arguments for drug law reform are gathering momentum globally. Despite a large body of empirically-oriented policy research, the area remains under-developed conceptually and theoretically. This paper seeks to address this gap by assembling some intellectual resources for a critical socio-legal analysis of drug law reform, drawing on insights from regulation studies, economics, political economy and economic sociology. Reframing the problem as one of market regulation, and using Shearing's constitutive approach, opens up some new ways of thinking about how drug laws function and the possibilities for reform. It also highlights the importance of taking normative thinking about drug policy futures seriously. In conclusion, it is suggested that a new concept of exchangespace may be key to further theoretical development in this field.
\end{abstract}

\section{Keywords}

Drugs, regulation, economics, political economy, markets, governance

The problem of drugs [is...] a market phenomenon. (Michel Foucault, $21^{\text {st }}$ March 1979 [Foucault 2008:257])

\section{Introduction}

The consumption of psychoactive substances is a practice that stretches back deep into human history and has been found in most cultures and societies around the world (Goodman et al 1995; Porter and Teich 1995; Courtwright 2001). Acknowledging this longue durée is important - the desire for intoxication is not a symptom of a spiritual malaise peculiar to 
today's world, even if modern consumer culture has sharpened some aspects of this human predilection (Brook 2010; Alexander 2010; Smith and Raymen 2018). Getting intoxicated appears to be simply one of the things that human beings have invariably done throughout history. Indeed, Siegel (1989) famously described the desire for intoxication as the fourth fundamental driver of human behaviour, after hunger, thirst and sex.

In contrast, the use of the criminal law to prohibit the trade in certain intoxicating substances is a relatively recent development, dating back around one hundred years to the beginning of the twentieth century (Bewley-Taylor 1999). The scope, scale and consequences of global drug prohibition have significantly escalated since its inception, especially in recent decades as 'war on drugs' rhetoric has led to increasingly punitive drug policies (Rolles et al 2016). Over 180 countries are now parties to the United Nations drug control treaties. Globally every year, at least US\$100 billion are spent in attempting to enforce national drug laws, countless arrests are made by the police, hundreds of thousands of people end up in prison convicted of drug offences (Rolles et al 2016), and several hundred drug offenders are executed (Sander 2018) ${ }^{1}$. Drug law enforcement has also long been a particular source of racial injustice, underpinning discriminatory practices at all stages of the criminal justice process (Glasser 2000; Eastwood et al 2013; Shiner et al 2018) and some have argued that racist discourse is embedded in the origins of prohibition (e.g. Seddon 2016).

Global drug prohibition should therefore be a significant concern for critical scholars right across the social sciences. Although there has certainly been some insightful and interesting work conducted from within multiple disciplines over the decades, arguably the area of drug law and policy has been somewhat neglected by researchers compared to studies of drugusing behaviour or drug distribution. In the last 20 years, this imbalance has to some extent been redressed through some exemplary policy research by the likes of Peter Reuter, Robert MacCoun, Alison Ritter, Jonathan Caulkins and others. Nevertheless, although this body of work has been executed with immense analytical skill and sophistication, it has been driven in the main empirically rather than theoretically. In this area, within the usual scholarly division of labour, it is the theoreticians who have been in dereliction of duty, whilst the empirical researchers have made outstanding contributions.

Why should we worry about this? It could be argued that the work of a scholar like Peter Reuter has been far more effective in addressing the challenges of reforming drug law and 
policy than any theorist could ever be. In many respects, that is entirely true. But theoretical work and conceptual discussion can complement policy-oriented empirical studies, deepening and widening enquiry and understanding. Now seems like a particularly good time to try to broaden out research, as over the last 15 years the tectonic plates of global drug policy have started to shift, with experiments in decriminalisation and legalisation springing up across Europe, South America, North America, Australia, the Caribbean and, most recently, Africa ${ }^{2}$ (see Eastwood et al 2016 for a global survey). New theoretical and conceptual tools can potentially help us not only in making sense of this changing world but also in informing the development of specific law reform initiatives. This paper seeks to make a start on this project by assembling some theoretical resources for critical socio-legal thinking about drug law reform. In doing so, it draws on scholarship from regulation studies, economic sociology, political economy, and economics, in order to develop a new approach built on the crossdisciplinary 'state of the art' of theoretical understandings of society-market interactions.

The paper begins by briefly sketching the main features of contemporary drug problems and the ways in which the global prohibition paradigm has failed, as this sets out the context in which drug law reform has achieved its current salience. The central part of the paper develops the argument for understanding drug laws as a form of market regulation. It argues for a constitutive conception of drug control, drawing on Shearing's (1993) work, in which regulation is understood not simply as a form of external market ordering but also as constituting the very markets it seeks to control. A short concluding section outlines how this constitutive perspective might be developed in the future in order to advance critical thinking about drug law reform.

\section{Global drug problems and the failures of prohibition}

Although the drug trade is legally prohibited within a framework of United Nations Conventions $^{3}$, it is estimated there are 275 million drug users globally, representing $5.6 \%$ of the world's population aged between 15 and 64 (UNODC 2018). The majority are cannabis smokers but there are also 31 million users of opiates, cocaine or amphetamines and around 11 million injectors (UNODC 2018). According to estimates, the value of the annual global retail market could be as much as US $\$ 320$ billion (UNODC 2005) $)^{4}$. The global disease 
burden associated with drug use is substantial. Excluding sub-Saharan Africa, injecting drug users account for nearly one third of all new HIV infections reported globally and there are 1.7 million drug users living with HIV (UNODC 2016a:14-15). One in every 100 deaths amongst the 15-64 population is attributable to drug use (UNODC 2012:7). Injecting drug users in particular have a very elevated risk of death, compared to the general population (Mathers et al 2013). Harms associated with production and trafficking are also significant. For some substances, notably heroin and cocaine, involvement in drug production has largely been concentrated in poorer countries and has exacerbated security and development issues, as, for example, in Afghanistan, the world's largest producer of opium (UNODC 2016b). Countries which lie on drug trading routes also suffer serious harms, including violence, organised crime and the corruption of officials, as we see, for example, in West Africa, a transit region for cocaine trafficking from South America to Europe (Carrier and Klantschnig 2012; Aning and Pokoo 2014). In richer countries, the drug trade is linked to problems of crime (Bennett et al 2008), inequalities (Stevens 2011:13-32) and public health (Middleton et al 2016).

Assuming the purpose of a prohibition system is to eliminate the market, we might draw the conclusion that it has been a spectacular failure. Indeed, there is strong evidence that decades of substantial expenditures on law enforcement have been associated with a trend of declining drug prices, the precise opposite of what would be expected if enforcement was effective $^{5}$ (Basov et al 2001; MacCoun and Reuter 2011: 66-67; Pollack and Reuter 2014). From this perspective, claims that the drug trade would be even bigger without prohibition (e.g. UNODC 2012:93) can be read simply as haggling about the degree of the system's failure. But the situation is even worse: prohibition is not only ineffective, it actually causes harms. The damaging impacts of prohibition on levels of violence in drug markets (Werb et al 2011; Jacques et al 2016), involvement of organised crime in the drug trade (Reuter 2014) and aspects of public health (Csete et al 2016) have all been extensively documented.

How has this happened? This is a complex but important question. A starting point for an answer is the recognition that the assembly a century ago of the global prohibition system was not a direct response or attempted solution to a new problem. Rather, it was driven by a complex set of foreign policy and economic interests of certain powerful (and largely Western) nations (Bewley-Taylor, 1999). This is critical to understand because it tells us that power, politics and trade have always been at the heart of drug prohibition, even when policy 
discourses have emphasised other concerns like health or morality. In this sense, a work like Alfred McCoy's (1972) The Politics of Heroin - which uncovered CIA involvement in the heroin trade in Southeast Asia in the 1960s - documents a strategy that falls squarely within the parameters of prohibition rather than being an aberration. The messy history of Western involvement in Afghanistan since 1979 provides an even clearer example of this intertwining of geopolitical concerns with international drug policy (see: Paoli et al 2009:111-130; Mansfield 2016).

After the advent of prohibition in the 1920s, global drug use remained relatively small-scale for the next couple of decades, and mainly confined to the US, Europe and China (van Duyne and Levi, 2005:24-28). Since the 1950s, we have seen two parallel developments. First, a trend of rising drug consumption and the geographical spread of the drug trade into parts of the world that had previously avoided it, starting with Eastern Europe (Csémy et al 2002), moving across parts of Asia (McKetin et al 2008) and, most recently, into Africa (Dewing et al 2006; Carrier and Klantschnig 2012), leading to today's globalised drug market ${ }^{6}$ (UNODC 2012:66-69). Second, at the same time, a hardening of the international prohibition regime (Bayer and Ghodse 1999), notably the passing of the UN Single Convention on Narcotic Drugs in 1961 which is often taken as the beginning of the distinctively punitive orientation of contemporary drug prohibition, encapsulated in Nixon's famous declaration in 1971 of a 'war on drugs'. The fact that these have been parallel developments - the tighter the screw is turned, the worse the problem gets - has been one of the recurring themes of critical accounts of drug law and policy: the 'paradox of prohibition' as a sage observer once put it (Marks 1990).

One way to make sense of this paradox is to view it in the context of the post-war development of capitalism (Thomas 2003; Seddon 2014). As Levi-Faur (2005) and others (Braithwaite 2008) have argued, we live today in a world of global regulatory capitalism in which both markets and regulation have become more vibrant, strongly shaped by globalising forces. This applies as much to 'markets in vice' as it does to 'markets in virtue' (Braithwaite 2008). The notion of regulatory capitalism is particularly useful as it captures the centrality of regulation to the contemporary capitalist order. In other words, the 'concept reasserts the inseparable, intimate and interdependent relations between politics, society and the economy' (Levi-Faur 2017:289). The phenomenon of the 'paradox of prohibition' can be understood then as a specific instance of this more general dynamic of regulatory capitalism. It is the 
unprecedented vibrancy of markets in recent decades - the increasing global flows of people, money and things - that has underpinned the growth and spread of contemporary drug supply (Seddon 2008:721-3). It is the rise of consumer culture that has helped to generate increasing drug demand (Seddon 2008:724). It is the continuing expansion of regulatory activity across diverse spheres that has contributed to calls for ever tighter regulatory controls on (aspects of) those markets. Taking the long view, we can see that this connection between the drug trade and the capitalist order has even deeper roots. According to economist Jeffrey Sachs (1999:91), the 1839-42 Opium War' between Britain and China was the 'first conflict of the modern capitalist era' and a critical part of the story of how the foundations of contemporary capitalism were built (see Lovell 2011). The concept of regulatory capitalism is therefore important in keeping our focus on analysing regulation in the 'broader context of changes in the forms of capitalism and the state' (Picciotto 2017:691), a critical perspective that is vital to examining drug law reform through the lens of regulation.

\section{Drug control and market ordering}

Understanding drug law and policy as a form of market regulation - and the challenge of drug law reform as a regulatory problem - provides a distinctive analytical vantage point. It highlights in particular the importance of focusing on precisely how legal or policy interventions affect the operation of drug markets. At a theoretical level, this requires a critical understanding of the relationship between markets and regulation. As Picciotto (2017:676) observes, this involves addressing fundamental questions about the interactions between the 'public sphere of politics and the state [... and] the 'private' sphere of economic activity and social relations', interactions often mediated through law. This framing also resonates with Lange and Haines (2015:14) who argue that 'rethinking economy-society interactions needs to be at the core of transforming approaches to regulation'.

\section{Drug control as external ordering}

These questions about markets and regulation have been preoccupations within economic thought for a long time. In the Wealth of Nations, first published in 1776, Adam Smith articulated what would become a central tenet of classical liberal economics: the idea that market ordering is a largely autonomous process which emerges 'naturally' through human 
interactions that occur as part of exchange relations (as captured in his famous metaphor of the 'invisible hand'). Much of the debate in the nineteenth century within classical liberalism - in works by John Stuart Mill, David Ricardo, Thomas Malthus and others - was essentially about whether, and in what circumstances, state interference with autonomous market ordering could be tolerated.

This debate continued into the twentieth century. The Cambridge economist Arthur Pigou argued in his influential 1920 text The Economics of Welfare that the proper basis for state interventions in market transactions was in order to address market malfunctioning. He developed the concept of 'externalities' to refer to social costs generated for third parties by such malfunctioning and argued that interventions to address externalities should normally take the form of government taxes or subsidies. Pigouvian welfare economics came under sustained critique from the 1960s, in the wake of Ronald Coase's (1960) landmark paper on 'The Problem of Social Cost' which inspired the 'law and economics' movement at the University of Chicago. The Chicagoans - including Richard Posner, Gary Becker, George Stigler and others - shared Pigou's view that market failures were the only appropriate grounds for regulatory intervention but argued for a very significantly more limited scope for governmental action, on the basis that economic actors were usually capable of negotiating efficient outcomes without external interference. Indeed, Coase (1960:18) in his original paper expressly stated that 'government regulation should be curtailed' and was only appropriate if it could be shown to produce a 'superior level of welfare' (Campbell 2017:40).

Although Coase and Pigou are often viewed as occupying opposing positions, in an important sense they share the same 'root image' of the relationship between markets and regulation (Shearing 1993:71). Shearing (1993:68) describes this as a 'control conception' of regulation, built on the broader idea of 'social order as a pre-political, pre-social phenomena that creates itself simply through the interaction of innate human characteristics'. In the rare cases where the 'invisible hand' of market ordering fails to secure the public interest and to maximise social utility, then regulation may be required, defined as an 'interference that seeks to control or impede the operation of market forces' (1993:69). On this point, Campbell (2018:551-555) draws an important distinction between what he terms ex post and ex ante regulation. The former category concerns regulatory interventions directed at an already established market, whereas the latter describes the regulation required for a particular market to exist. We will return to this point later. 
The more recent sub-field of information economics is in a similar 'control' vein. In his foundational 1970 paper 'A market for lemons', Akerlof (1970:488) developed a theory to explain the complex 'interaction of quality differences and uncertainty' within markets, focusing on the importance of information flows to the effective functioning of economic exchange relations. Using the example of the used car trade, he explained how under conditions of information asymmetry - where a potential purchaser has limited information about the quality of the product on offer and little or no opportunity to test for quality prior to purchase - a 'market for lemons' can be created (a 'lemon' being a car of sub-standard quality). In this situation, an individual seller has little incentive to market higher quality goods, as the benefits from doing so will accrue primarily to car vendors as a group, rather than to the individual seller. As a result, over time average product quality will tend to fall and the aggregate size of the market will be reduced. In extreme cases, this may eventually lead to complete market failure. Akerlof (1970:499-500) identified consumer guarantees, 'brand names' and licensing practices as 'counteracting institutions' which could limit the problem of 'lemons markets'. Again, we can understand these institutions as regulatory interventions required when, as a result of information asymmetries, the 'invisible hand' generates too many costs or externalities if left unfettered.

Much of the drug law reform literature implicitly draws on this control conception of regulation. In one of the most insightful and influential critiques of prohibition, Ethan Nadelmann (1992:90) notes, first of all, that for 'hard-core' libertarians, 'no governmental controls on the commerce in drugs are acceptable', on the grounds of the sanctity of personal freedom and property rights. He goes on to suggest that for more pragmatic libertarians, it is their faith in the free market that leads to the view that drug policy objectives 'would best be accomplished in the absence of governmental interventions', a position entirely consistent with 200 years of classical liberal thought from Smith to Coase. Indeed, a perennial source of support for drug legalisation comes from free-market liberal thinkers. Post-Coase Chicagoan scholars like Richard Epstein and Richard Posner have on occasion expressly put forward precisely that view (see Harcourt 2011:231-233), as has the UK-based neoliberal think-tank the Adam Smith Institute (e.g. Pryor and McCulloch 2019). Nadelmann's (1992:96) own adoption of the control conception is evident when he describes part of the intellectual challenge of thinking seriously about alternatives to prohibition as centring on the question of how best to 'maximise the benefits of the free market model and minimise its risks'. This 
resonates strongly with Coase in particular and his view that the market mechanism can do much of the work of generating positive outcomes with only a residual and limited necessity to rely on regulatory controls by the state. An important contribution by Rolles (2010:128) in the British Medical Journal similarly conceptualises drug legalization as an external intervention in a poorly functioning market, when he observes that 'non-medical drug markets can remain in the hands of unregulated criminal profiteers or they can be controlled and regulated by appropriate government authorities'.

Part of what is meant by reformers like Rolles when they describe drug markets as 'unregulated' is that within a prohibition system it is very difficult to provide adequate product information to consumers. From a consumer protection perspective this is a major problem, as providing consumers with accurate and relevant information is fundamental (Howells 2005). From a market functioning perspective, it is conducive to a 'market for lemons', characterised by poor and inconsistent product quality, driven by information asymmetries between buyers and sellers (Reuter and Caulkins 2004). For reformers, drug markets structured around such asymmetries lead to an unacceptably high level of costs and externalities (e.g. overdoses, deaths) which therefore justifies regulatory intervention. Some recent harm reduction innovations can be understood as functioning as one of Akerlof's 'counteracting institutions' by providing purchasers with better product information. For example, 'pill testing' or 'drug checking' services at music festivals and clubs - which aim to provide consumers with in situ information about the content and purity of substances prior to consumption - have developed as an informational mechanism for reducing harm and protecting health (for a global review, see Barratt et al 2018; see also Measham 2019). Similarly, a feature of drug-selling websites on the 'darknet', which have proliferated in recent years, has been the inclusion of rating systems for products and sellers. It has been argued that these feedback systems on product quality enable a form of 'comparison shopping' that may improve consumer safety (Aldridge et al 2018).

An insightful paper by economic sociologists Beckert and Wehinger (2013) seeks to extend Akerlof's model to the context of illegal markets (see also: Bakken et al 2018; Moeller 2018). They move beyond simply looking at the problem of information asymmetry to a wider assessment of the ways in which different types of illegal markets face distinctive coordination problems concerning what they term valuation (assessing product quality), competition (struggles between market competitors) and co-operation (trust in market actors 
to fulfil agreements). They go on to describe how market actors find particular ways of mitigating and circumventing these problems through adaptive practices. What this nuanced analysis starts to highlight is the dynamic and interactive relationship between market behaviour and regulation. Regulation is evidently not simply an external constraint applied to a market that has an independent or prior existence, rather it helps to produce or constitute the market in a specific form. This market form or structure then generates particular patterns of adaptation to the specific co-ordination problems present in the market, which may, in turn, prompt new regulatory action that will then re-constitute the market in a different form. It is this understanding of market-regulation relations as a 'continually evolving and dynamic process' (Campbell and Picciotto 1998) which lies at the heart of what Shearing (1993) describes as a constitutive conception of regulation.

\section{A constitutive conception of drug control}

The idea that regulation is productive or constitutive rather than simply negative or constraining is partly a Foucauldian one (Foucault 1977:194). An older version of the idea can be found in the work of the Freiburg School of Law and Economics founded in the 1930s (Vanberg 1999). The Freiburg group, also known as the ordoliberals, understood market processes as unfolding in the context of prior institutional frameworks. Vanberg (1999:224) defines the ordoliberal approach as 'constitutional liberalism', in contrast to strict free-market liberalism, starting from the premise that the "market order, as defined by its institutional framework, is a matter of, and is subject to, (explicit or implicit) constitutional choice' and that the 'working properties of market processes depend on the nature of the legalinstitutional framework within which they take place'. Illustrating this perhaps unlikely theoretical connection between French poststructuralist philosophy and pre-war German economics, Foucault offers a fascinating analysis of ordoliberalism in the fourth, fifth and sixth lectures of this 1979 course at the Collège de France (Foucault 2008:75-157; see also Gane 2014). A different branch of this intellectual genealogy is a line of thought within economic sociology associated with the concept of the social 'embeddedness' of markets, as set out in a landmark article by Granovetter (1985) and derived from the work of Karl Polanyi (1944). In recent years, within regulation studies there has been a revival of interest in Polanyi's relevance to contemporary thinking about regulation and markets (e.g. the edited collection by Lange et al 2015) and this has also influenced socio-legal thought in this area (e.g. Cotterrell 2013). 
As Campbell and Klaes (2005:278) correctly observe, contrary to caricatures of neoliberal market economics, Coase acknowledges the necessity of ex ante regulation to establish the legal framework within which economic activity takes place. Shearing (1993) starts from this position - that markets do not have a pure pre-regulatory existence, that is, they are not 'natural phenomena' (1993:71) created out of unmediated human interaction - but then considerably extends the argument. For Shearing (1993:72), markets are a 'regulatory accomplishment' rather than a phenomenon that precedes or stands apart from regulation. They are created out of regulatory regimes and shaped by prior and ongoing allocations of resources. Hence the very idea of market deregulation is a chimera. In blunt terms, 'there is no escape from the necessity of regulation [...] no unconstituted market to which to turn nor is there market ordering that will relieve us of the task of regulation' (1993:71). In a similar vein, Harcourt (2011:47-48) questions whether the categories of 'free' and 'regulated' are useful terms at all for classifying forms of market organisation. He argues that these are invented rather than natural categories and traces their genealogy back to the French Enlightenment and the pre-Smith ${ }^{8}$ writings of François Quesnay and the Physiocrats in the middle of the eighteenth century (2011:50-51) ${ }^{9}$. Where the Physiocrats wrote of the 'natural order' of markets, in the twentieth century this became Hayek's 'spontaneous order' and, later on, the notion of 'market efficiency' as developed by Coase and the Chicagoans (Harcourt 2011:121-150). The shared assumption throughout this lineage of liberal economic thought is that the notion of 'free markets' is a meaningful category, and that regulation is a form of external interference with market processes. For both Harcourt and Shearing, however, all markets are organised through regulation of some kind and the most important task is to identify what distributive consequences or outcomes flow from particular regulatory regimes or arrangements. In perhaps the single most influential work in regulation studies, Responsive Regulation, Ayres and Braithwaite (1992) similarly frame the relationship between markets and regulation as a dynamic and interactive one, in which regulation has to respond to industry conduct or structure which it also plays a major part in shaping.

A constitutive perspective shines a very different light on drug control. Rather than conceiving of some points on the continuum of drug control as involving a de facto absence of regulation (e.g. strict prohibition or complete liberalisation), each point is understood as a distinctive regulatory regime which constitutes the market in a particular way. This idea that drug prohibition is just another form of regulation may be challenging. It certainly runs counter to the standard narratives of drug law reformers. But if we take seriously the 
definitions of regulation developed within regulation studies - for example, Julia Black's (2002:26) 'the sustained and focused attempt to alter the behaviour of others according to defined standards or purposes' or John Braithwaite's (2008:1) 'steering the flow of events' then it becomes almost self-evidently the case. As Beckert and Wehinger (2013:11-20) discuss, criminalising trade in a particular product or service shapes market behaviour and market structure. For example, in criminalised markets, the lack of legal enforceability of exchange agreements at different points in the supply chain, can lead to, inter alia, a reliance on threatened or actual violence as a resource for doing business, a preference for trading within networks of known and trusted parties, and a tendency for enterprises to remain relatively small. Similarly, the limited scope for potential buyers to determine product quality and value prior to purchase, can lead to a greater emphasis on the importance of reputation established and communicated within personalised networks. In other words, criminalisation clearly 'steers the flow of events' within the market in distinctive ways. In quite an important sense, therefore, prohibitive drug laws are a form of legal regulation of the drug trade.

How might we 'think constitutively' about drug control and drug law reform? Shearing (1993:72) suggests that the metaphor of regulatory space, first developed by Hancher and Moran (1989), is a critical component for a constitutive analysis. This is the idea that regulation can be conceived as taking place in a space in which there may be multiple regulatory schemes and influences. Shearing (1993:72) argues that from this viewpoint to focus solely on state regulation is therefore a 'peculiar and conservative' response to most regulatory problems, because it represents an approach which is 'content to leave the shape of the regulatory space in question essentially unchanged and to concern itself exclusively with the presence or absence of the state'. For drug control, the policy debate tends to be narrower still: it is not about the presence of the state but rather about what form state interventions should take (e.g. criminalisation or legalisation). Thinking in terms of regulatory space moves us away from the notion that regulation is an external control that can be turned on or off and that the drug policy task is to find the right balance of constraints on otherwise self-ordering markets. Rather, drug markets are constituted by the shape and contours of the regulatory space in which they are positioned and however we describe our approach - prohibition, legalization, decriminalization, or depenalization - that regulatory space is never empty. All regimes of regulation produce their corresponding markets. 
Developing this further, as Colin Scott (2001) observes, a central insight of the regulatory space metaphor is that regulatory resources, powers and capacities are dispersed and fragmented, across and within state and non-state bodies. It follows that 'reform' of any regulatory regime is not solely or even primarily a matter of adjusting state actions or laws but rather involves a renegotiation of the entire configuration of resources and relations within that space. As Shearing (1993:72) puts it, a constitutive approach 'insists that regulatory space as a whole should be made the subject of regulatory policy'. Drug law reform therefore cannot just be about changing the legal framework for drug markets and deciding whether or not to use the criminal law. It has to engage on a much broader footing with a reorientation and reshaping of the totality of relations within the regulatory space, including but not restricted to state agencies. A good example of this approach - although they do not cite Hancher and Moran (1989) - is provided by Dorn and White (1999) in a highly original essay which explores the 'opportunities for a regulatory space' through a study of how a diverse range of civil law and administrative measures can by deployed at municipal level in order to regulate local drug problems. This 'decentring' of the state within notions of regulation - in contrast to traditional 'command and control' models - has been a strong theme within regulation studies over the last 20 years (see Black 2001) and also resonates with Foucauldian analyses of how power functions within neo-liberalism, as in Rose and Miller's (1992) much-cited paper on 'political power beyond the state'. In more recent work, Shearing and his collaborators have sought to bring these two theoretical literatures together, under the sign of 'nodal governance' (e.g. Burris et al 2005; Holley and Shearing 2017).

To explore how we might use this idea - a decentred state within a regulatory space - to think differently about drug law reform, we must turn to the inter-disciplinary field of regulation studies for our intellectual resources. One set of related and overlapping concepts - termed variously regulatory surrogates (Abbot 2012), regulatory intermediaries (Abbott et al 2017), or third-party policing (Mazerolle and Ransley 2006) - focuses on the diversity of actors who can be involved in regulatory activities. It moves away from the notion that regulation is essentially a bilateral activity involving rule-makers and rule-takers. Instead, it is conceived as a multi-party process with multiple actors performing a variety of roles and functions within it. Regulatory intermediaries (or surrogates) - those parties who are neither rulemakers nor the targets of regulation - can be private actors, civil society groups, or state bodies, and can operate domestically or transnationally. As Abbott et al (2017) note, within 
the regulatory space, there can be chains of intermediaries within complex regulatory systems. Others have preferred to think in terms of regulatory webs rather than chains (e.g. Braithwaite and Drahos 2000), to reflect better this complexity, whilst others still have preferred the notion of polycentric or nodal governance (e.g. Burris et al 2005). A key insight that cuts across this family of concepts is that regulatory design will be more effective if it pays attention to the full range of actors who potentially have a stake in the regulatory enterprise. A good example is offered by Ramsay (2006) who shows how consumer protection advocates can have much greater impact by working with payment intermediaries in the global credit card system than they ever could through trying to shift national government consumer law or policy. Another set of concepts that covers similar terrain comes under the umbrella term meta-regulation: in essence, regulated self-regulation (for a useful overview, see Grabosky 2017). Meta-regulation - and its close cousins regulatory pluralism and self-regulation - is based on the premise that the regulatory enterprise takes place under the auspices of a diverse set of institutions and actors, and that therefore a pragmatic approach is to delegate responsibility for regulation to that broad cast of characters and then monitor how that responsibility is discharged.

Applying these ideas to drug law reform offers a way of broadening out our understanding of where the regulatory levers are to be found. If we take the example of online 'darknet' drug markets, some policy-makers have attempted simply to translate traditional drug prohibition approaches for the new problem. As Scott (2004) suggests, however, in the online context, this mode of 'hierarchical application' of rules is simply unfit for purpose and there is a need for what he terms regulatory innovation. Thinking then with these sets of concepts regulatory intermediaries and meta-regulation - we can start to see some different possibilities. We can, for example, map actual and potential occupants of the regulatory space: internet service providers, website administrators, vendors, purchasers, other members of online communities, law enforcement agents (online and offline), transport services, customs officials, mail delivery services, home insurers, and so on. A regulatory strategy can then be built by thinking through how these different actors might be enlisted, incentivised or otherwise 'steered' to contribute to regulatory goals. Empirical studies of these markets have started to show how online communities with a distinctive self-regulatory character appear to have emerged, as site users share information about product quality and safety in ways that may reduce harm (Aldridge et al 2018). The scope for imaginative meta-regulatory strategies is very clear (for further discussion, see Seddon 2014; for an empirical example relating to 
illicit drugs, see Cherney et al 2006). Here we begin to see a radical redistribution of the tasks of regulation, such that the line between regulator and regulatee is not so much blurred as almost entirely effaced, and the centrality of law and state agencies comes under serious challenge. This is a destination unlikely to be reached using the traditional intellectual resources of lawyers or criminal justice scholars, which tend, for obvious reasons towards a view of the world that keeps the state centre-stage.

A further implication of a constitutive perspective concerns the relationship between rules and outcomes within the regulatory enterprise. As we have seen, much of the debate about drug law reform is framed in a way that treats state-centred laws and rules as the heart of the matter. From the perspective of decentred regulation, however, this focus is too narrow. As Shearing (1993:77) observes, from a constitutive viewpoint, the 'essence of regulation is not compliance with rules but rather the constitution of an order understood as a state of affairs'. In other words, the core task is to imagine what the desired order looks like, instead of concentrating on creating new systems of rules and new enforcement regimes. This, in turn, requires an explicit engagement with normative questions. As Braithwaite (2000:87) has remarked, social scientists rarely take normative thinking - the development of 'ordered propositions about the way the world ought to be' - very seriously. But a constitutive conception of drug control requires us to engage our regulatory imagination on these difficult questions. It is for this reason that the common call by drug law reformers to take politics out of debates about drug policy, to base such discussions exclusively on science and evidence, is misguided. A constitutive understanding of the relationship between markets and regulation necessitates thinking about what order or state of affairs we are trying to create and that ultimately is a matter of political values. This helps us to understand in theoretical terms why the attempt to eliminate the political in debates about drug law reform is simply impossible. We should not, of course, make the mistake of concluding that if markets are constituted we can mould them in whatever way we like - as Campbell (2016:94) observes, governmental failure is as much an issue as market failure - but, equally, the responsibility to grapple seriously and transparently with the politics of drug control should not be evaded.

A normative orientation is particularly important when considering the regulation of those drug markets in which trade is transnational, such as European heroin markets which are sourced mainly from opium poppies grown in Afghanistan and distributed through the Balkans (UNODC 2016a:26). Empirically, we know that this type of supply chain requires us 
to pay attention to issues of poverty, development and security in producer and transit countries. As Braithwaite (2013:134-135) powerfully argues, Western consumer countries should not approach the regulatory task by ignoring the harms 'caused to deliver our consumption'. Drug law and policy, in other words, is a matter of international political economy which requires a 'transnational regulatory vision' that is alive to the potential for 'exploitative consumption' in more developed countries (Braithwaite 2013:135). Buxton (2015) argues that both prohibitionists and reformers have at times failed to address adequately the question of how to protect rural livelihoods in producer countries. This has been recognised much more clearly for other agricultural commodities, like coffee, sugar, or cotton, with Fairtrade an example of an NGO-led market intervention designed to address this problem (see: Johannessen and Wilhite 2010; Raynolds 2018). In terms of theoretical and conceptual resources, the political economy literature has much to offer here. For example, the work of Gary Gereffi and colleagues on the governance of what they term 'global value chains' (Gereffi et al 2005) provides an entire grammar and vocabulary not only for understanding how these chains work but also how to regulate them in ways that minimise inequalities and enhance rights and justice. It is here that we see most clearly that drug law reform involves engaging with a set of questions about regulatory capitalism, requiring us to reconnect our analysis of markets with the wider social and political context of contemporary capitalism. As Picciotto (2017:691) puts it, we should resist seeing regulation purely as an apolitical technical matter of finding solutions to policy problems and understand it instead as always related to the balance between market, state and civil society.

Adopting this constitutive conception of drug control is challenging. It requires us to draw together and synthesise diverse theoretical and conceptual resources from across several disciplines. In this section, an account has been sketched of how this might start to be done, as part of the development of critical thinking about drug law reform. It has been argued that this is vital if socio-legal and criminal justice scholars are to contribute fully to the rapidlyevolving landscape of global law reform that appears to be gathering increasing momentum. In the short concluding part of the paper, some ideas for how to take this intellectual agenda further forward are briefly set out. 


\section{Conclusions}

The core argument running through this paper has been that drug law and policy should be understood as a type of market regulation, with the drug law reform debate reframed as a discussion about how to regulate drug markets more effectively. Intrinsic to the argument is the notion that prohibition - the attempted prevention or elimination of the drug trade - is itself a form of regulation, rather than its absence. It follows that scholars studying drug policy and thinking about drug law reform have much to learn potentially from the diverse and extensive social science literature on markets and regulation. The paper makes a preliminary effort to assemble some of these theoretical and conceptual resources as a means of advancing thinking in this area. No doubt there is more that can be done to develop this intellectual project and deeper collaborative engagements with economists, regulation scholars, economic sociologists and political economists will be essential for this endeavour.

It has been argued, further, that in the context of drug law reform, the most fruitful way of articulating theoretically the relationship between markets and regulation is through Shearing's constitutive conception of regulation and its related notion of regulatory space. This opens up new ways of thinking about the possibilities for drug control that take us considerably beyond our traditional centring of state agencies and legal instruments. Although reforming international treaties and national drug laws are undoubtedly important, regulatory resources and capacities are to be found across multiple actors and agencies. The imaginative harnessing of third parties, intermediaries and other non-state actors needs to be at the heart of strategies for the better regulation of markets in intoxicating substances.

The additional requirement Shearing's approach places on us to take normative questions seriously is also a profoundly important one. Whatever else it might be, drug prohibition has become an expensive global machine for generating social and racial injustice, and so the imagination and creation of a post-prohibition world is an essential task for critical scholars (see Nadelmann 2004). Thinking in a serious, structured and systematic way about what that world should look like has arguably been an under-developed activity in some of the drug law reform initiatives of recent years, where the focus has tended to be more on the binary questions of whether or not to legalise or decriminalise. For future research, there is also an important connection to be made here with the ongoing work of Loader and Sparks (2014) to 
develop what they term a 'better politics of crime'. Part of their project involves embracing rather than denying the highly political character of crime policy and, as has been argued in this paper, this is equally important for thinking about drug law reform. By using Shearing's constitutive framework, and Levi-Faur's concept of regulatory capitalism, it has been shown that embracing the political is a requirement that is generated theoretically rather than being merely a matter of scholarly preference for engagement.

The pay-off of this theoretical and conceptual framework for drug policy and drug law reform may be significant. Whilst the account at the start of the paper of the longue durée of human engagement with intoxicating substances underlined that this is a transhistorical and transcultural phenomenon, it equally highlighted the relative novelty of using the criminal law to prohibit trade in a specific sub-set of those substances. In the long run, drug prohibition will most likely prove to be a transitory state of affairs and we will need to find alternative approaches. By connecting this legal and policy challenge with wider thinking on markets and regulation, we open up a much broader range of intellectual resources for imagining, creating, understanding and evaluating those new approaches. Instead of domination by criminologists and lawyers, which is largely an artefact of the nature of the current prohibition regime, the field should develop a more appropriately cross-disciplinary profile. As scholars have begun to argue in relation to global food systems (e.g. Parker and Johnson 2019), in effect the 'drug question' is one particular strand within the bigger debate about how we should regulate capitalism in the twenty-first century. For example, current anxieties in the United States about the dangers of the emergence of 'Big Marijuana' (e.g. Richter and Levy 2014) can be best understood - and addressed - in this light.

At a more general theoretical level, the constitutive perspective set out in this paper also points towards the potential for a radical conceptual development for the future. What precisely does it mean to say that there is no such thing as an unregulated market? One answer to this type of question is to resist the established binary of 'regulation' and 'market' (Lange and Haines 2015) and consider whether they are better understood as simply different aspects of the same thing. In other words, just as post-Einstein physicists think of spacetime as a single concept, or Giddens-influenced sociologists talk of the duality of structure, perhaps markets and regulation need to be viewed not as separate realms but rather as two sides of the same coin. Perhaps there is only what we might term an exchangespace, in which the 'market' and 'regulation' dimensions are fused together. The exploration and elaboration 
of this idea is a theoretical task for the future, and one which is likely to be relevant not only to the critical analysis of drug law reform but also more broadly to many legal or policy challenges that centre on the question of how to control and regulate economic activity, from food regulation to money laundering.

\section{Acknowledgements}

Earlier versions of this paper were presented in Oxford, Toronto and Vancouver and I am grateful for questions and feedback from participants. Special thanks for reading and commenting on a draft to John Braithwaite, David Campbell, Bronwen Morgan and Clifford Shearing. The usual disclaimer applies.

\section{Notes}

1. As well as legal executions, the problem of extrajudicial killings associated with the prosecution of the 'war on drugs' has recurred in several parts of the world, including the Philippines, Bangladesh, Thailand and Mexico (see reports from international NGO Human Rights Watch).

2. Africa was in fact the focus of the first international agreement on the trade of psychoactive substances, the Brussels General Act of 1889-90, which sought to restrict the traffic of alcohol within colonial Africa (see Pan 1975). Until very recently, African countries have followed a fairly strict drug prohibition approach. Recent developments in Ghana (see Ane 2018), South Africa (where the Constitutional Court has decriminalised the private cultivation and use of cannabis) and Lesotho (where a licence to cultivate medical cannabis was granted in 2017) suggest that drug law reform may be starting to gain traction there.

3. Single Convention on Narcotic Drugs of 1961 as amended by the 1972 Protocol; Convention on Psychotropic Substances of 1971; Convention against Illicit Traffic in Narcotic Drugs and Psychotropic Substances of 1988. 
4. For useful discussions of the difficulties in sizing the global drug market, see Reuter and Greenfield (2001) and Thoumi (2005).

5. Caulkins and Reuter (2010) provide a 'state of the art' review of the literature on the relationship between drug enforcement and drug prices. As well as observing this apparently paradoxical phenomenon of increased enforcement intensity being linked to declining prices, they go on to show how the enforcement-price relationship is in fact considerably more complex than this.

6. The drug trade is now 'global', in the sense that its traded commodities have world-wide availability. It is not, however, a single globally-integrated market but rather a set of separate regional markets organised around substances, production sources and trading routes. This distinction has been much debated by economists and in the globalization literature - see Perraton (2001).

7. In the middle of the nineteenth century, a protracted trade dispute led to two armed conflicts between China and the British Empire, known as the 'Opium Wars'. The first (1839-42) was aimed at halting the enforcement of restrictions on the importation into China of opium cultivated in the Bengal province in British India. The second (1856-60) forced China to legalise this trade. Lovell (2011) provides an engaging and insightful account, arguing that the shadow of these conflicts has shaped Sino-Western relations over the last 170 years.

8. The intellectual relationship between Adam Smith and the Physiocrats is well-trodden ground in the history of economic ideas (e.g. Young 2002).

9. This point is also made by Foucault in the second lecture of the 1979 Collège de France course (Foucault 2008:30-32). 


\section{References}

Abbot, C. (2012) 'Bridging the Gap - Non-state Actors and the Challenges of Regulating New Technology' Journal of Law and Society 39(3) 329-358.

Abbott, K., Levi-Faur, D. and Snidal, D. (2017) 'Theorizing Regulatory Intermediaries: The RIT Model' The ANNALS of the American Academy of Political and Social Science 670 1435.

Akerlof, G. (1970) 'The Market for "Lemons": Quality Uncertainty and the Market Mechanism' Quarterly Journal of Economics 84(4) 488-500.

Aldridge, J., Stevens, A. and Barratt, M. (2018) 'Will growth in cryptomarket drug buying increase the harms of illicit drugs?' Addiction 113(5) 789-796.

Alexander, B. (2010) The Globalization of Addiction: A study in poverty of the spirit. Oxford: Oxford University Press.

Ane, M.-G. (2018) Ghana Strives for a More Humane Drug Policy. GDPO Situation Analysis. Swansea: GDPO.

Aning, K. and Pokoo, J. (2014) 'Understanding the nature and threats of drug trafficking to national and regional security in West Africa' Stability: International Journal of Security and Development 3(1) p.Art. 8.

Ayres, I. and Braithwaite, J. (1992) Responsive Regulation: Transcending the Deregulation Debate. Oxford: Oxford University Press.

Bakken, S., Moeller, K. and Sandberg, S. (2017) 'Coordination problems in cryptomarkets: Changes in cooperation, competition and valuation' European Journal of Criminology 15(4) $442-460$. 
Barratt, M., Kowalski, M., Maier, L.J., and Ritter, A. (2018) Global review of drug checking services operating in 2017. Drug Policy Modelling Program Bulletin No. 24. Sydney, Australia: National Drug and Alcohol Research Centre, UNSW Sydney.

Basov, S., Jacobson, M. and Miron, J. (2001) 'Prohibition and the Market for Illegal Drugs' World Economics 2(4) 1-25.

Bayer, I. and Ghodse, H. (1999) 'Evolution of international drug control, 1945-1995' Bulletin on Narcotics LI (1 and 2) 1-17.

Beckert, J. and Wehinger, F. (2013) 'In the shadow: illegal markets and economic sociology' Socio-Economic Review 11(1) 5-30.

Bennett, T., Holloway, K. and Farrington, D. (2008) 'The statistical association between drug misuse and crime: A meta-analysis’'Aggression \& Violent Behavior 13 107-118.

Bewley-Taylor, D. (1999) The United States and International Drug Control, 1909-1997. London: Continuum.

Black, J. (2001) 'Decentring Regulation: Understanding the Role of Regulation and SelfRegulation in a "Post-Regulatory" World' Current Legal Problems 54 103-147.

Black, J. (2002) ‘Critical Reflections on Regulation' Australian Journal of Legal Philosophy $271-37$.

Braithwaite, J. (2000) 'Republican theory and crime control' in: S. Karstedt and K.-D. Bussmann (eds) Social Dynamics of Crime and Control: New Theories for a World in Transition. Oxford: Hart.

Braithwaite, J. (2008) Regulatory Capitalism: How it works, ideas for making it work better. Cheltenham: Edward Elgar. 
Braithwaite, J. (2013) 'Relational republican regulation' Regulation \& Governance 7 124144.

Braithwaite, J. and Drahos, P. (2000) Global Business Regulation. Cambridge: Cambridge University Press.

Brook, H. (2010) 'Choosing Using: Drug policy, consumer culture and 'junkie' manquées' Cultural Studies 24(1) 95-109.

Burris, S., Drahos, P. and Shearing, C. (2005) 'Nodal Governance' Australian Journal of Legal Philosophy 30 30-58.

Buxton, J. (2015) Drugs and Development: The Great Disconnect. Policy Report 2. Swansea: Global Drug Policy Observatory, Swansea University.

Campbell, D. (2016) 'Ronald Coase's 'The Problem of Social Cost' University of Queensland Law Journal 35(1) 75-98.

Campbell, D. (2017) 'The Sense in Coase's Critique of Pigou: The Ceteris Paribus Case for Intervention' Journal of Law, Economics and Policy 13(1) 39-54.

Campbell, D. (2018) 'The 'Market' in the Theory of Regulation' Social \& Legal Studies $27(5) 545-571$.

Campbell, D. and Klaes, M. (2005) 'The principle of institutional direction: Coase's regulatory critique of intervention' Cambridge Journal of Economics 29 263-288.

Campbell, D. and Picciotto, S. (1998) 'Exploring the interaction between law and economics: the limits of formalism' Legal Studies 18(3) 249-278.

Carrier, N. and Klantschnig, G. (2012) Africa and the War on Drugs. London: Zed Books.

Caulkins, J. and Reuter, P. (2010) 'How Drug Enforcement Affects Drug Prices' Crime and Justice: A Review of Research 39 213-271. 
Cherney, A., O’Reilly, J. and Grabosky, P. (2006) 'Networks and Meta-regulation: Strategies Aimed at Governing Illicit Synthetic Drugs’ Policing \& Society 16(4) 370-385.

Coase, R. (1960) 'The Problem of Social Cost' Journal of Law \& Economics 3 1-44.

Cotterrell, R. (2013) ‘Rethinking ‘Embeddedness': Law, Economy, Community’ Journal of Law and Society 40(1) 49-67.

Courtwright, D. (2001) Forces of Habit: Drugs and the making of the modern world. Cambridge, MA: Harvard University Press.

Csémy, L., Kubička, L. and Nociar, A. (2002) 'Drug Scene in the Czech Republic and Slovakia during the Period of Transformation' European Addiction Research 8 159-165.

Csete, J., Kamarulzaman, A.,Kazatchkine, M. et al (2016) 'Public Health and International Drug Policy: Report of the John Hopkins - Lancet Commission on Drug Policy and Health' The Lancet 387(10026) 1427-1480.

Dewing, S., Plüdemann, A., Myers, B. and Parry, C. (2006) 'Review of injection drug use in six African countries: Egypt, Kenya, Mauritius, Nigeria, South Africa and Tanzania' Drugs: Education, Prevention and Policy 13(2) 121-137.

Dorn N. and White, S. (1999) 'Drug trafficking, nuisance and use: opportunities for a regulatory space' in: N. Dorn (ed) Regulating European Drug Problems: Administrative measures and civil law in the control of drug trafficking, nuisance and use. The Hague: Kluwer Law International.

Eastwood, N., Shiner, M. and Bear, D. (2013) The Numbers in Black and White: Ethnic Disparities in the Policing and Prosecution of Drug Offences in England and Wales. London: Release.

Eastwood, N., Fox, E. and Rosmarin, A. (2016) A Quiet Revolution: Drug Decriminalization Across the Globe. $2^{\text {nd }}$ Edition. London: Release. 
Foucault, M. (1977) Discipline and Punish: The birth of the prison. London: Allen Lane.

Foucault, M. (2008) The Birth of Biopolitics: Lectures at the Collège de France, 1978-1979. Basingstoke: Palgrave Macmillan.

Gane, N. (2014) 'The Emergence of Neoliberalism: Thinking Through and Beyond Michel Foucault's Lectures on Biopolitics' Theory, Culture \& Society 31(4) 3-27.

Gereffi, G., Humphrey, J. and Sturgeon, T. (2005) 'The governance of global value chains' Review of International Political Economy 12(1) 78-104.

Glasser, I. (2000) ‘American Drug Laws: The New Jim Crow’ Albany Law Review 63703.

Goodman, J., Lovejoy, P. and Sherratt, A. (eds) (1995) Consuming Habits: Drugs in History and Anthropology. London: Routledge.

Grabosky, P. (2017) ‘Meta-regulation' in: P. Drahos (ed) Regulatory Theory: Foundations and Applications. Canberra: ANU Press.

Granovetter, M. (1985) 'Economic Action and Social Structure: The Problem of Embeddedness' American Journal of Sociology 91(3) 481-510.

Hancher, L. and Moran, M. (1989) 'Organizing Regulatory Space’ in: L. Hancher and M. Moran (eds) Capitalism, Culture and Economic Regulation. Oxford: Oxford University Press.

Harcourt, B. (2011) The Illusion of Free Markets: Punishment and the Myth of Natural Order. Cambridge, MA: Harvard University Press.

Holley, C. and Shearing, C. (2017) 'A nodal perspective of governance: Advances in nodal governance thinking' in: P. Drahos (ed) Regulatory Theory: Foundations and Applications. Canberra: ANU Press. 
Howells, G. (2005) 'The potential and limits of consumer empowerment by information' Journal of Law and Society 32(3) 349-370.

Jacques, S., Rosenfeld, R., Wright, R. and van Gemert, F. (2016) 'Effects of Prohibition and Decriminalization on Drug Market Conflict' Criminology \& Public Policy 15(3) 843-875.

Johannessen, S. and Wilhite, H. (2010) 'Who Really Benefits from Fairtrade? An Analysis of Value Distribution in Fairtrade Coffee' Globalizations 7(4) 525-544.

Lange, B. and Haines, F. (2015) 'Regulatory Transformations: An Introduction' in: B. Lange, F. Haines and D. Thomas (eds) Regulatory Transformations: Rethinking Economy-Society Interactions. Oxford: Hart.

Lange, B., Haines, F. and Thomas, D. (eds) (2015) Regulatory Transformations: Rethinking Economy-Society Interactions. Oxford: Hart.

Levi-Faur, D. (2005) 'The Global Diffusion of Regulatory Capitalism' Annals of the American Academy of Political and Social Science 598 12-32.

Levi-Faur, D. (2017) 'Regulatory Capitalism’ in: P. Drahos (ed) Regulatory Theory: Foundations and Applications. Canberra: ANU Press.

Loader, I. and Sparks, R. (2014) 'The Question of Public Criminology: Seeking Resources of Hope for a Better Politics of Crime' International Annals of Criminology 52(1-2) 155-177.

Lovell, J. (2011) The Opium War: Drugs, Dreams and the Making of China. London: Picador.

MacCoun, R. and Reuter, P. (2011) 'Assessing Drug Prohibition and Its Alternatives: A Guide for Agnostics' Annual Review of Law \& Social Science 7 61-78.

McCoy, A. (1972) The Politics of Heroin in Southeast Asia. London: HarperCollins. 
McKetin, R., Kozel, N., Douglas, J. Ali, R. et al (2008) 'The rise of methamphetamine in Southeast and East Asia' Drug and Alcohol Review 27(3) 220-228.

Mansfield, D. (2016) A State Built on Sand: How Opium Undermined Afghanistan. Oxford: Oxford University Press.

Marks, J. (1990) 'The Paradox of Prohibition' in: J. Hando and J. Carless (eds) Controlled Availability: Wisdom or Disaster? National Drug and Alcohol Research Centre Monograph No 10. Sydney: NDARC.

Mathers, B., Degenhardt, L., Bucello, C. et al (2013) 'Mortality among people who inject drugs: a systematic review and meta-analysis' Bulletin of the World Health Organisation 91(2) 102-123.

Mazerolle, L. and Ransley, J. (2006) Third Party Policing. Cambridge: Cambridge University Press.

Measham, F. (2019) 'Drug safety testing, disposals and dealing in an English field: Exploring the operational and behavioural outcomes of the UK's first onsite 'drug checking' service' International Journal of Drug Policy.

Middleton, J., McGrail, S. and Stringer, K. (2016) 'Drug related deaths in England and Wales' British Medical Journal 355 i5259.

Moeller, K. (2018) 'Drug Market Criminology: Combining Economic and Criminological Research on Illicit Drug Markets' International Criminal Justice Review 28(3) 191-205.

Nadelmann, E. (1992) 'Thinking Seriously About Alternatives to Drug Prohibition' Daedalus 121(3) 85-132.

Nadelmann, E. (2004) 'Criminologists and Punitive Drug Prohibition: To Serve or To Challenge?' Criminology \& Public Policy 3(3) 1001-1010.

Pan, L. (1975) Alcohol in Colonial Africa. Helsinki: Finnish Foundation for Alcohol Studies. 
Paoli, L., Greenfield, V. and Reuter, P. (2009) The World Heroin Market: Can Supply Be Cut? Oxford: Oxford University Press.

Parker, C. and Johnson, H. (2019) 'From Food Chains to Food Webs: Regulating Capitalist Production and Consumption in the Food System' Annual Review of Law \& Social Science.

Perraton, J. (2001) 'The global economy - myths and realities' Cambridge Journal of Economics 25 669-684.

Picciotto, S. (2017) 'Regulation: Managing the Antinomies of Economic Vice and Virtue' Social \& Legal Studies 26(6) 676-699.

Polanyi, K. (1944) The Great Transformation: The Political and Economic Origins of Our Time. Boston: Beacon Press.

Pollack, H. and Reuter, P. (2014) 'Does tougher enforcement make drugs more expensive?' Addiction 109(12) 1959-1966.

Porter, R. and Teich, M. (eds) (1995) Drugs and Narcotics in History. Cambridge: Cambridge University Press.

Pryor, D. and McCulloch, L. (2019) The Green Light: How legalising and regulating cannabis will reduce crime, protect children and improve safety. London: Adam Smith Institute.

Ramsay, I. (2006) 'Consumer Law, Regulatory Capitalism and the 'New Learning' in Regulation' Sydney Law Review 28(9) 9-35.

Raynolds, L. (2018) 'Fairtrade Certification, Labor Standards, and Labor Rights:

Comparative Innovations and Persistent Challenges'Sociology of Development 4(2) 191-216.

Reuter, P. (2014) 'Drug Markets and Organized Crime' in: L. Paoli (ed) The Oxford Handbook of Organized Crime. Oxford: Oxford University Press. 
Reuter, P. and Caulkins, J. (2004) 'Illegal "lemons": price dispersion in cocaine and heroin markets' Bulletin on Narcotics LVI(1 and 2) 141-165.

Reuter, P. and Greenfield, V. (2001) 'Measuring Global Drug Markets: How good are the numbers and why should we care about them?' World Economics 2(4) 159-173.

Richter, K. and Levy, S. (2014) ‘Big Marijuana - Lessons from Big Tobacco’ New England Journal of Medicine 371 399-401.

Rolles, S. (2010) ‘An alternative to the war on drugs' British Medical Journal 341:c3360.

Rolles, S., Murkin, G., Powell, M. et al (2016) The Alternative World Drug Report. $2^{\text {nd }}$ Edition. Bristol: Transform Drug Policy Foundation.

Rose, N. and Miller, P. (1992) 'Political power beyond the State: problematics of government' British Journal of Sociology 43(2) 173-205.

Sachs, J. (1999) 'Twentieth-Century Political Economy: A Brief History of Global Capitalism' Oxford Review of Economic Policy 15(4) 90-101.

Sander, G. (2018) The Death Penalty for Drug Offences: Global Overview 2017. London: Harm Reduction International.

Scott, C. (2001) 'Analysing Regulatory Space: Fragmented Resources and Institutional Design’ Public Law 283-305.

Scott, C. (2004) 'Regulatory Innovation and the Online Consumer' Law \& Policy 26(3\&4) 477-506.

Seddon, T. (2008) 'Drugs, the informal economy and globalization' International Journal of Social Economics 35(10) 717-728. 
Seddon, T. (2014) 'Drug policy and global regulatory capitalism: The case of new psychoactive substances (NPS)' International Journal of Drug Policy 25(5) 1019-1024.

Seddon, T. (2016) 'Inventing Drugs: A genealogy of a regulatory concept' Journal of Law and Society 43(3) 393-415.

Shearing, C. (1993) 'A Constitutive Conception of Regulation' in: P. Grabosky and J. Braithwaite (eds) Business Regulation and Australia's Future. Canberra: Australian Institute of Criminology.

Shiner, M., Carre, Z, Delsol, R. and Eastwood, N. (2018) The Colour of Injustice: 'Race', drugs and law enforcement in England and Wales. London: Release.

Siegel, R. (1989) Intoxication: Life in the pursuit of artificial paradise. New York: E P Dutton.

Smith, O. and Raymen, T. (2018) 'Deviant leisure: A criminological perspective' Theoretical Criminology 22(1) 63-82.

Stevens, A. (2011) Drugs, crime and public health: The political economy of drug policy. Abingdon: Routledge.

Thomas, C. (2003) 'Disciplining Globalization: International Law, Illegal Trade, and the Case of Narcotics' Michigan Journal of International Law 24 549-575.

Thoumi, F. (2005) 'The Numbers Game: Let's all guess the size of the illegal drugs industry!' Journal of Drug Issues 35(1) 185-200.

United Nations Office on Drugs and Crime (UNODC) (2005) World Drug Report 2005. Vienna: United Nations.

United Nations Office on Drugs and Crime (UNODC) (2012) World Drug Report 2012. Vienna: United Nations. 
United Nations Office on Drugs and Crime (UNODC) (2016a) World Drug Report 2016. Vienna: United Nations.

United Nations Office on Drugs and Crime (UNODC) (2016b) Afghanistan Opium Survey 2016: Cultivation and Production. Vienna: United Nations.

United Nations Office on Drugs and Crime (UNODC) (2018) World Drug Report 2018. Booklet 1, Executive Summary. Vienna: United Nations.

van Duyne, P. and Levi, M. (2005) Drugs and Money: Managing the drug trade and crimemoney in Europe. London: Routledge.

Vanberg, V. (1999) 'Markets and Regulation: On the Contrast Between Free-Market Liberalism and Constitutional Liberalism' Constitutional Political Economy 10 219-243.

Werb, D., Rowell, G., Guyatt, G. et al (2011) 'Effect of drug law enforcement on drug market violence: A systematic review' International Journal of Drug Policy 22(2) 87-94.

Young, J. (2002) 'Adam Smith and the Physiocrats: Contrasting Views on the Law of Nature' History of Economic Ideas 10(3) 7-28. 